\title{
Research Paper \\ Comparison of the effectiveness of acceptance and commitment therapy and dialectical behavioral therapy on self-efficacy of divorced women under the auspices of the imam khomeini relief committee and behzisti organization
}

Hossein Raeisi ${ }^{1}$, Mohsen Rasouli ${ }^{2}$, Abdolrahim Kasaee ${ }^{2}$

1. Ph.D Candidate, Department of Counseling, Kharazmi University, Tehran, Iran.

2. Assistant Professor, Department of Counseling, Kharazmi University, Tehran, Iran.

Citation: Raeisi H, Rasouli M, Kasaee A. Comparison of the effectiveness of acceptance and commitment therapy and dialectical behavioral therapy on self-efficacy of divorced women under the auspices of the imam khomeini relief committee and behzisti organization. J of Psychological Science. 2021; 20(106): 1733-1747.

URL: https://psychologicalscience.ir/article-1-1113-fa.html
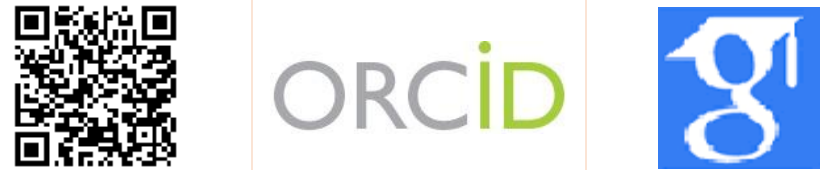

$\underline{10.52547 / J P S .20 .106 .1733}$

\section{A R T I C L E I F O A B S T A C T}

Keywords:

Divorce,

Divorced Women,

Self-Efficacy,

Acceptance and

Commitment Therapy,

Dialectical Behavior

Therapy

Received: 11 Jan 2021

Accepted: 10 Feb 2021

Available: 22 Dec 2021
Background: Women, after divorce, do not have enough self-efficacy to cope with life's problems and stresses, and literatures show the increase of self-efficacy by acceptance and commitment and dialectical behavior therapy, two important treatments in the third wave, but it is not clear which one is more effective.

Aims: The purpose of this study was to determine comparison of the group therapy based on acceptance and commitment and dialectical behavior therapy on self-efficacy in divorced women. Methods: The research method was quasi-experimental. The statistical population included all divorced women in Eghlid in 2019, 24 of whom selected with available sampling and randomly divided into acceptance and commitment therapy group, dialectical behavior therapy group, and the control group. One experimental group received acceptance and commitment therapy intervention (n $=8)$ and the other group received dialectical behavior therapy intervention $(n=8)$ in 12 sessions of 90 minutes. Individuals completed the self-efficacy Questionnaire of Sherer, \& Adams, (1982) before, after and 2 months after the treatments. Research data were analyzed using repeated measures analysis of variance and simple effects of the group by spss-22 software.

Results: The results showed that group therapy based on acceptance and commitment and dialectical behavior therapy increase the self-efficacy of divorced women $(\mathrm{P}<0.05)$ but there is no significant difference between the two therapies $(\mathrm{P}>0.05)$.

Conclusion: Therefore, it can be concluded that to increase self-efficacy of divorced women both group therapy based on acceptance and commitment and dialectical behavior therapy can be used in psychotherapy sessions.

* Corresponding Author: Mohsen Rasouli, Assistant Professor, Department of Counseling, Kharazmi University, Tehran, Iran.

E-mail: dr.rasouli@hotmail.com

Tel: (+98) 9126725761

2476-5740/ (C) 2021 The Authors. This is an open access article under the CC BY-NC-ND license

(https://creativecommons.org/licenses/by-nc/4.0/). 


\section{Extended Abstract}

\section{Introduction}

Divorce is considered the collapse of the social and familial life (Afrasiabi \& Jafari Zade 2015). Defeats usually decrease the amount of self-efficacy (Kurbanoglu, 2003), so divorce decreases people's self-efficacy. Acceptance and Commitment Therapy (ACT) and Dialectical Behavior Therapy (DBT) are two treatment approaches used in the third wave. Acceptance and commitment therapy is the important functional factors in the relationship framework, according to which humans' suffer results from his psychological inflexibility strengthened by cognitive complexity and avoiding experiments (Hayes, Strosahl \& Wilson, 2014). Dialectical Behavior Therapy originates from behaviorism that includes both change and acceptance (Linehan, 2015b).

Although both methods have led to the increase in the self-efficacy, as shown by different studies (Lee \& Ha, 2018; Park, et al 2020), there are some potential opportunities for pursuing studies in both fields. A few studies have been done in the effectiveness of these two treatment approaches in the field of divorce and the increase in the divorced woman's selfefficacy. On the other hand, it is not completely clear which treatment approach is more effective for the increase of the self-efficacy, so that it can be exploited as the best treatment approach for divorced women, hence the decrease in the costs and time. Therefore, the present study aims to respond the question that "which of these two treatment approaches, ACT and DBT, is more effective on the divorced women's self-efficacy?

\section{Method}

The research method was quasi-experimental that included a pre-test, a post-test and a follow-up by a control group. The statistical population of the study included all divorced women in Eqlid in 2019, 24 of women were selected via available sampling and randomly divided into three groups: an Acceptance and Commitment Therapy group ( 8 cases), a Dialectical Behavior Therapy group (8 cases) and a control group (8 cases). Then the ACT group was provided with 12 weekly 90-minute sessions (Honarparvaran, et al., 2014), and the DBT group was provided with 12 weekly 90-minute sessions (Hadizade, et al., 2014) but there was not any session for the control group. Individuals completed the selfefficacy questionnaire of Sherer, \& Adams (1982) both before and 2 months after the treatments. The research data was analyzed using repeated measures analysis of variance and simple effects of the group by spss-22 software.

\section{Results}

The age range of the cases was between 29 to 54 . All of the assumptions of analysis of variance such as unrelated data, linearity hypothesis, and homogeniety of Co-variance-variance matrix, Shapiro-Wilk and Levene's test were confirmed. The meaningfulness level of Mauchly W scale confirmed the assumption of sphericity for the factor of self-efficacy, and this could show no freedom degree in groups $(p>0 / 5$, $\mathrm{w}=0 / 93)$.

The results showed that grouping was a functional factor ( $p<0 / 001, F=6 / 24)$, so there was a meaningful difference in the self-efficacy scores in three groups of ACT, DBT and the control group. As shown in the table 1, self-efficacy has been meaningful through time $(\mathrm{p}<0 / 01)$ and there was a difference between pretest, post-test and follow-up. In addition, the $\mathrm{F}$ amounts and Significance levels showed a significant difference in the experimental and the control group $(\mathrm{p}<0 / 01)$.

\begin{tabular}{ccccccccc}
\multicolumn{2}{c}{ Table 1. The result of repeated measures analysis of variance } \\
\hline \multirow{2}{*}{ factors } & Resources & $\begin{array}{c}\text { Sum of } \\
\text { squares }\end{array}$ & $\begin{array}{c}\text { degrees of } \\
\text { freedom }\end{array}$ & $\begin{array}{c}\text { Average } \\
\text { of squares }\end{array}$ & F & Significance & $\begin{array}{c}\text { The amount } \\
\text { of factor }\end{array}$ \\
\hline \multirow{2}{*}{ intergroup } & Time & $1170 / 111$ & 2 & $585 / 056$ & $35 / 23$ & $0 / 0001$ & - \\
& $\begin{array}{c}\text { Interaction of time and } \\
\text { group (interaction effect) }\end{array}$ & $853 / 222$ & 4 & $213 / 306$ & $12 / 847$ & $0 / 0001$ & - \\
intragroup & error & $697 / 333$ & 42 & $16 / 603$ & - & - & - \\
& group & $2540 / 778$ & 2 & $1270 / 389$ & $5 / 23$ & $0 / 01$ & - & - \\
\hline
\end{tabular}


The Bonferroni post hoc test showed that both treatment methods were effective on people's selfefficacy. The effectiveness of these two treatment methods on the self-efficacy were the same in the post-test. At the follow-up, self-efficacy was meaningful just in the ACT group (Table 2).

Table 2. Bonferroni post hoc test for comparison of the experimental group and the control group

\begin{tabular}{|c|c|c|c|c|c|c|c|}
\hline \multirow[t]{2}{*}{ Time } & \multirow[t]{2}{*}{ I group } & \multirow[t]{2}{*}{$\mathrm{J}$ group } & \multirow[t]{2}{*}{ Avarage variance (I-J) } & \multirow[t]{2}{*}{ Standard error } & \multirow[t]{2}{*}{ meaningfulness } & \multicolumn{2}{|c|}{$\begin{array}{l}95 \% \text { assurance distance } \\
\text { to the average variance }\end{array}$} \\
\hline & & & & & & Low level & High level \\
\hline \multirow{4}{*}{ Pre-test } & \multirow{2}{*}{$\mathrm{ACT}$} & DBT & $7 / 50$ & $4 / 54$ & $0 / 3$ & $-4 / 33$ & $16 / 33$ \\
\hline & & control & $5 / 37$ & $4 / 54$ & $0 / 7$ & $-6 / 46$ & $17 / 21$ \\
\hline & \multirow{2}{*}{ DBT } & $\mathrm{ACT}$ & $-7 / 50$ & $4 / 54$ & $0 / 3$ & $-19 / 33$ & $4 / 33$ \\
\hline & & control & $-2 / 12$ & $4 / 54$ & 1 & $-13 / 96$ & $9 / 71$ \\
\hline \multirow{4}{*}{ Post-test } & \multirow{2}{*}{ ACT } & DBT & $4 / 25$ & $4 / 56$ & 1 & $-7 / 62$ & $16 / 12$ \\
\hline & & control & $17 / 37$ & $4 / 56$ & $0 / 003$ & $5 / 50$ & $29 / 24$ \\
\hline & \multirow{2}{*}{ DBT } & ACT & $-4 / 25$ & $4 / 56$ & 1 & $-16 / 12$ & $7 / 62$ \\
\hline & & control & $13 / 12$ & $4 / 56$ & $0 / 02$ & $1 / 25$ & $24 / 99$ \\
\hline \multirow{4}{*}{ Follow-up } & \multirow{2}{*}{ ACT } & DBT & $4 / 75$ & $5 / 23$ & 1 & $-8 / 86$ & $18 / 26$ \\
\hline & & control & $20 / 50$ & $5 / 23$ & $0 / 002$ & $6 / 88$ & $24 / 11$ \\
\hline & \multirow{2}{*}{ DBT } & ACT & $-4 / 75$ & $5 / 23$ & 1 & $-18 / 36$ & $8 / 86$ \\
\hline & & control & $15 / 75$ & $5 / 23$ & $0 / 02$ & $2 / 13$ & $29 / 36$ \\
\hline
\end{tabular}

\section{Conclusion}

As shown by the study, both ACT and DBT can be effective on the increase of self-efficacy in divorced women and there was not any difference in this factor. In accounting for the effectiveness of ACT it can be said that acceptance is in the opposite side of the experimental avoidance. Facing with their current situation and accepting it, divorced women can have a proper estimation of their own great potentiality and can believe in themselves. This can greatly increase their self-efficacy in coping with their problems. In addition, it can be said that DBT can show the two different sides and consequences of any action, hence increase self-efficacy.

Both ACT and DBT can be some of the psychological pulses in divorced women through teaching some skills such as mindfulness, diffusion instead of avoiding thoughts and feelings, tolerating distresses, adjusting thrills and pursuing their own values. Therefore, the effect of the negative feelings on the divorced women's actions decreases, so there can be no meaningful difference here.

\section{Ethical Considerations}

Compliance with ethical guidelines: In order to respect ethical considerations, an agreement was designed and the experimental cases were promised to be studied secretly. The counselling sessions were held in Roshd Counselling Center privately. Finally, after the follow-up, some treatment sessions were held for some of the control group that were willing to get.

Funding: This study was conducted as a $\mathrm{PhD}$ thesis with no financial support

Authors' contribution: The first author was the senior author; the second was the supervisor and the third was the advisor. Conflict of interest: The authors declare no conflict of interest for this study.

Acknowledgments: I would like to appreciate the supervisor, the advisors, and the participants. 


\section{مقايسه اثربخشى گروهدرمانى مبتنى بر يذيرش و تعهد و رفتاردرمانى ديالكتيكى بر خود كار آمدى زنان مطلقه تحت}

\section{يوشش نهادهاى كميتهامداد امامخمينى و سازمان بهزيستى يستى}

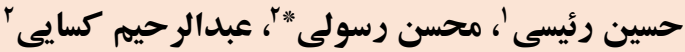

1. دانشجوى دكترى، گروه مشاوره، دانشكاه خوارزمى، تهر ان، ايران.

r. استاديار، گروه مشاوره، دانشكاه خوارزمى، تهران، ايران.

OU

زمينه: خود كار آمدى زنان بس از طلاق كاهش مىيابد كه بر مقابله آنها با مشكلات و استرسهاى زندگى تأثير مى گذارد. ادبيات بزوهشى افزايش خود كار آمدى را بعد از رويكردهاى درمان مبتى بر يذيرش و تعهد و رفتاردرمانى ديالكتيكى، كه جز روشهاى درمانى موج سوم

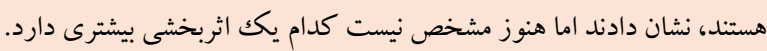
هدف: يُزوهش حاضر به دنبال مقايسه اثربخشى گروهدرمانى مبتنى بر پذيرش و تعهل و رفتاردرمانى ديالكتيكى بر خود كار آمدى در زنان مطلقه بود. روش: اين يثوهش بهصورت شبه آزمايشى با طرح ييش آزمون، بس آزمون و ييخيرى انجام شد. جامعه آمارى شامل كليه زنان مطلقه شهر

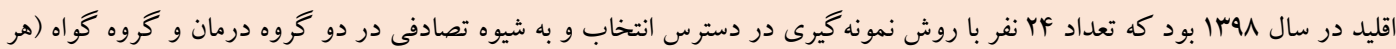
كروه ^نفر)، جايخزين شدند. يكى از گروههاى آزمايش مداخله درمان مبتنى بر يذيرش و تعهد (1 نفر ) و گروه ديخر مداخله رفتاردرمانى

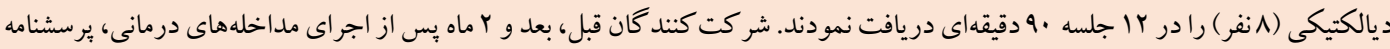
خود كار آمدى شرر و آدامز (19AY) را تكميل كردند. دادههاى ئزوهش با استفاده از نرمافزار

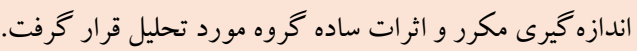
يافته ها: نتايج نشان داد كه درمان يذيرش و تعهد و رفتاردرمانى ديالكتيكى موجب افزايش خود كار آمدى زنان مطلقه مى شوند (ه./. > p)

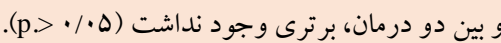

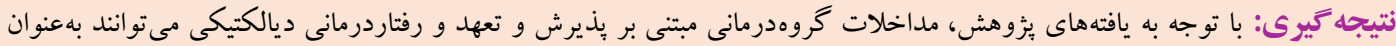
روشهايى كار آمد براى افزايش خود كار آمدى زنان مطلقه مورد استفاده قرار كيرند.
مشخصات مقاله

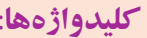

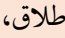

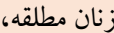

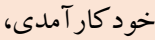

درمان مبتى بر بذيرش و تعهل،

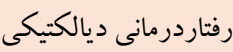

* نويسنده مسئول: محسن رسولى، استاديار، گُووه مشاوره، دانشگاه خوارزمى، تهران، ايران. رايانامه: dr.rasouli@hotmail.com

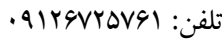


به تشديد احساسات، هيجانات و افكارى مى شود كه فرد سعى داشته از

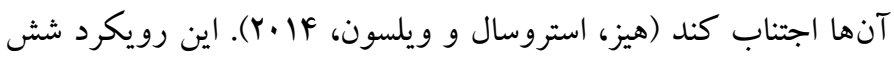

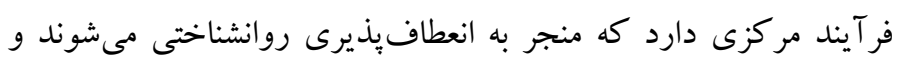

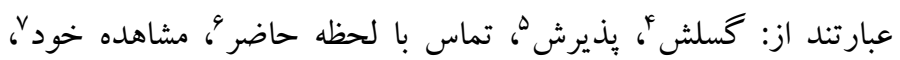

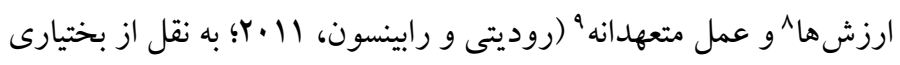

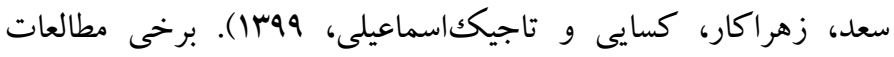
اثربخشى اين درمان را بر افزايش خودكار آمدى نشان دادهاند (لى و ها،

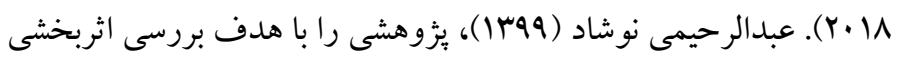

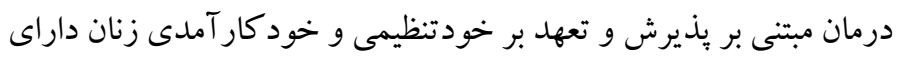

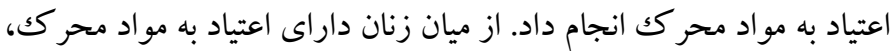

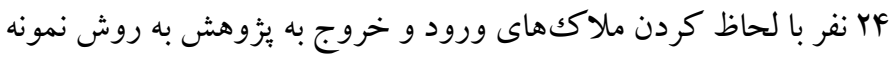
كيرى در دسترس انتخاب و بهشيوه تصادفى در دو گرووه آزمايش و كنترل

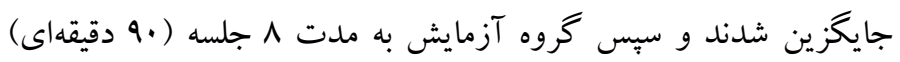

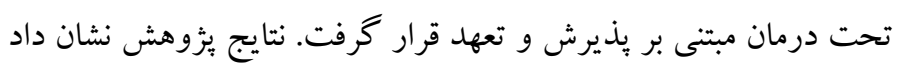

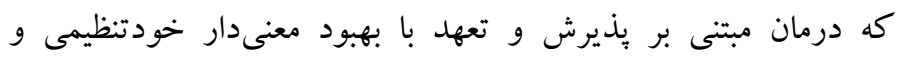
خود كار آمدى گروه آزمايش همر اه است.

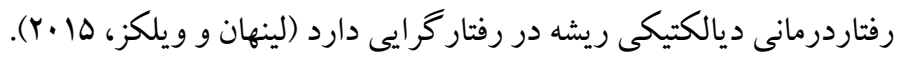

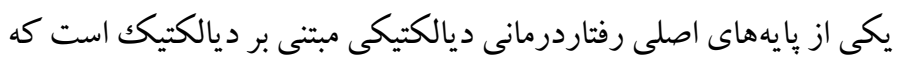

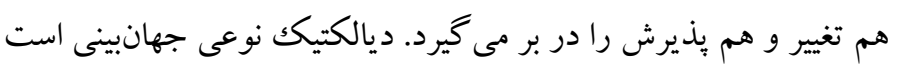

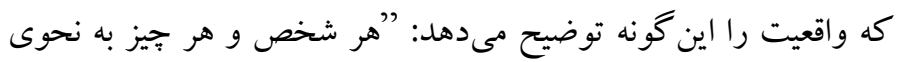

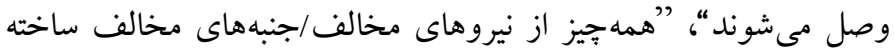

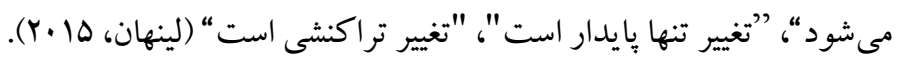

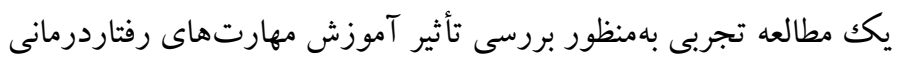

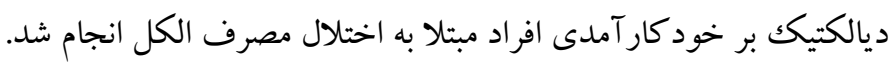
يافتها نشان داد كه خودكارآمدى بهطور معنىدارى بين سه دوره

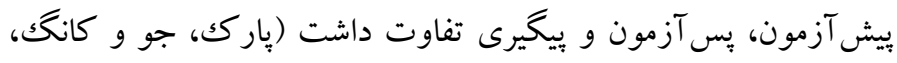

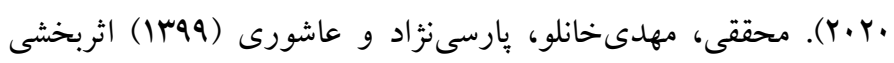

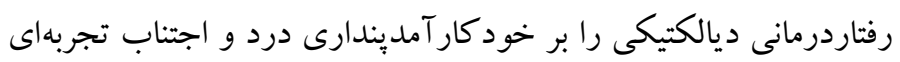

\footnotetext{
6. Contact with the Present Moment

7. Observing Self

${ }^{8}$. Values

9. Committed Action
}

مقام dold

طلاق'، يكك معضل اجتماعى در جهان و در كشور ما محسوب مىشود كه

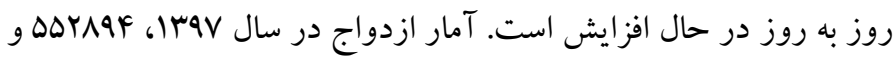
ميزان طلاق در همين سال IVGAYr مورد مىباشد. اين آمار براى سال

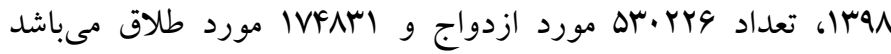

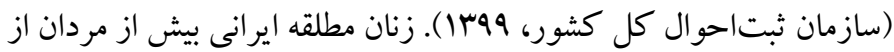

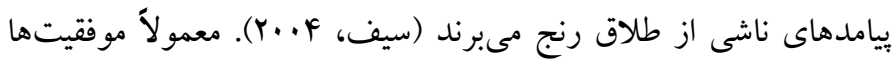
باعث خود كار آمدى مى شوند، درحالى كه شكست طها ميز ان آن ران را كاهش

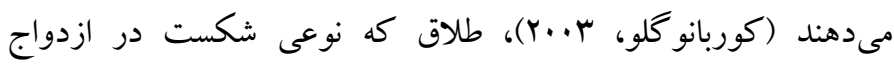
محسوب مى شود، خود كار آمدى افراد را كاهش مىدهد.

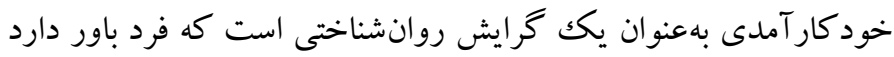
كه قادر به انجام و تكميل يكك فعاليت مىباشد (هرازى و ايروان، •Y.Y.Y.).

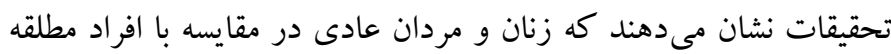

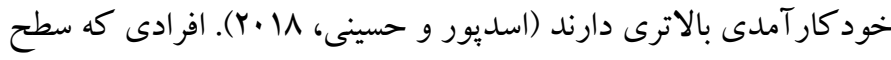

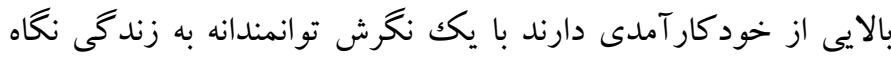

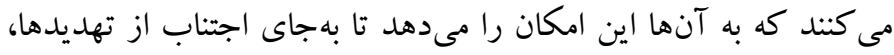

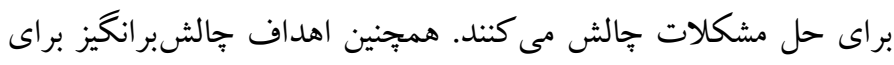

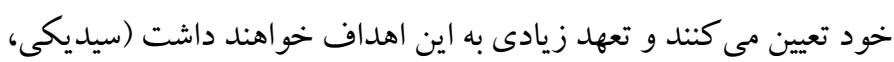

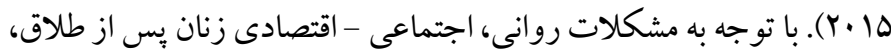
افزايش خود كار آمدى به آنان كمك مى كند تا با اين مشكلات كنار بيايند

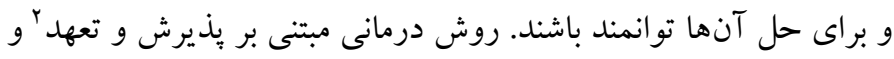

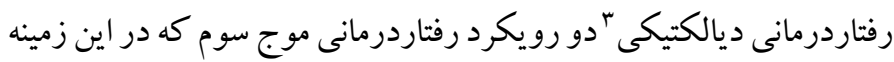
مورد استفاده قرار خرفتهاند. درمان مبتى بر بذيرش و تعهل بخشى از آنجه امروز موج سوم درمانى

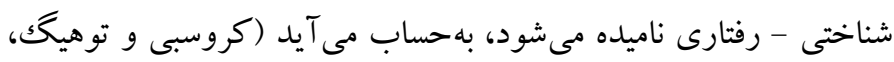

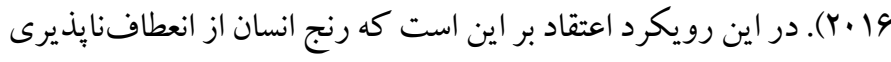
روانشناختى او حاصل مى شود كه با آميختكى شناختى و اجتناب تجربهها

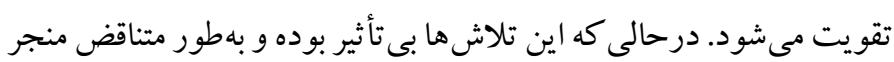

1. divorce

2. Aceptance and Commitment Therapy (ACT)

${ }^{3}$. Dialectical Behaviour Therapy (DBT)

${ }^{4}$. Defusion

5. Acceptance 
مبتنى بر بذيرش و تعهل و rا جلسه .9 دقيقهاى گروهدرمانى بهشيوه

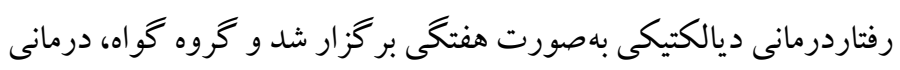

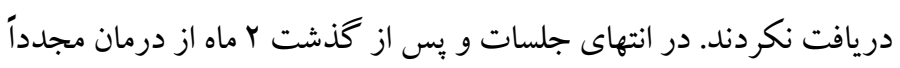

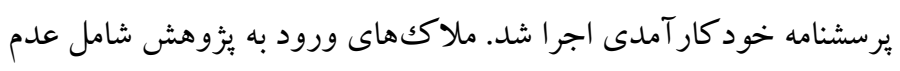

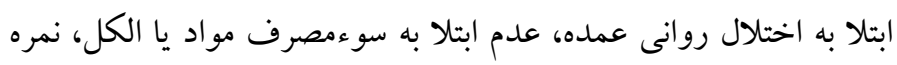

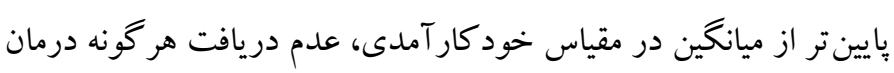

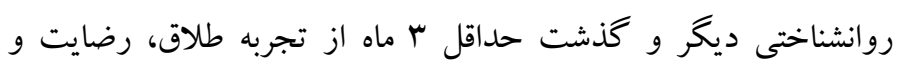

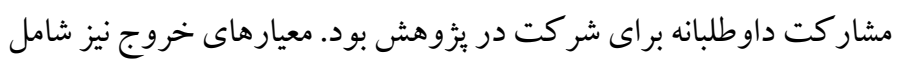

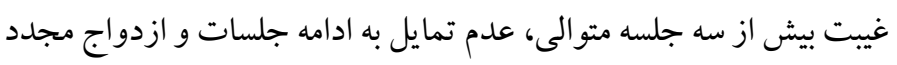

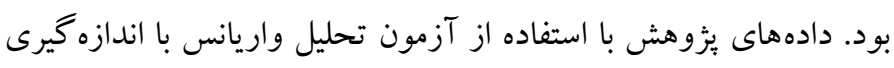

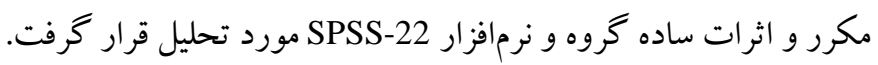

ب) ابزار يرسشنامه خود كار آمدى: اين برسشنامه توسط شرر و آدامز (19AY) ساخته

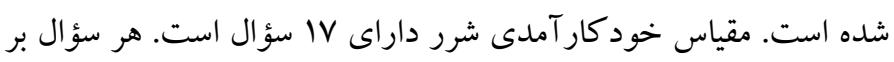
اساس مقياس ليكرت از دامنه كاملاً مخالفم تا كاملاً موافقم تنظيم مى شعود.

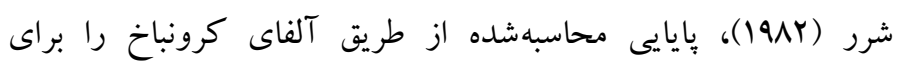

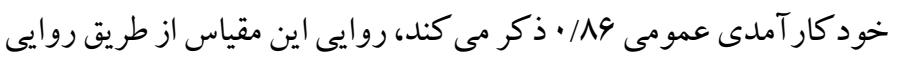

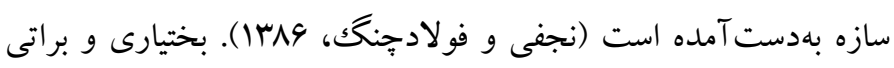

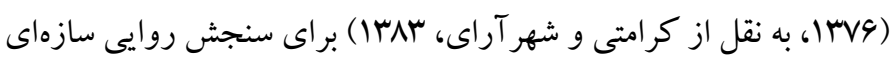

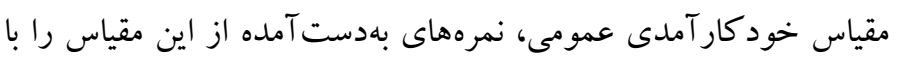

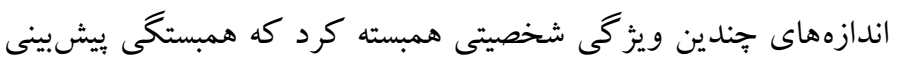

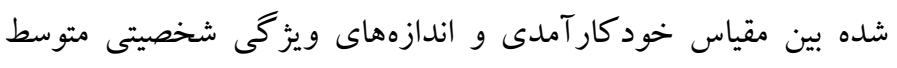

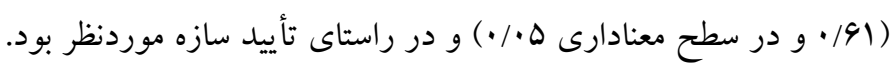
همجنين، ضريب بايايى برسشنامه از طريق تصنيف و با روش اسبيرمن براون

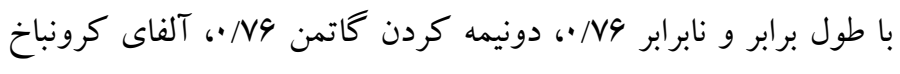

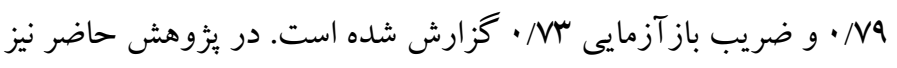
آلفاى كرونباخ سی/ • بهدست آمد. جلسات درمان يذيرش و تعهل در يُزوهش حاضر بر خرفته از برنامه مداخله

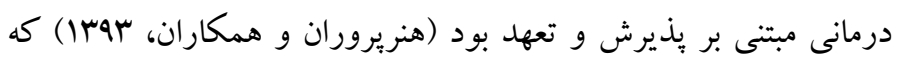
محتو اي جلسات درمانى به شرح ذيل است مئى بـاشد.
مادران مبتلا به سندروم روده تحريكگيذير بررسى كردند. تعداد .ب نفر از

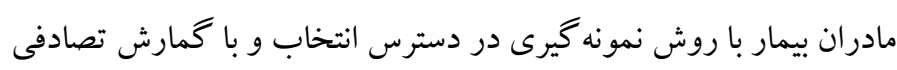

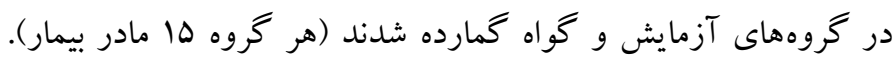

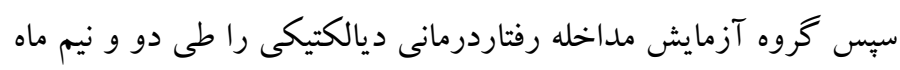

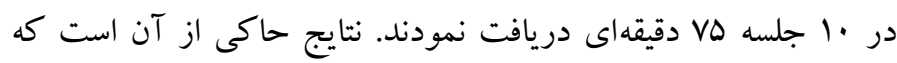

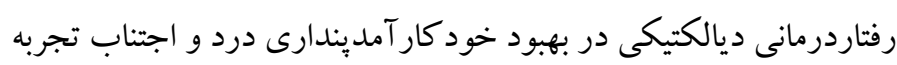
اى مادران مبتلا به سندروم روده تحريككيذير تأثير معنى دار دارد.

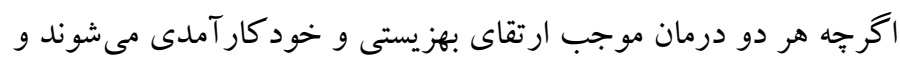

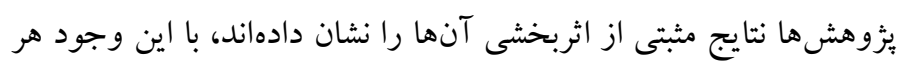

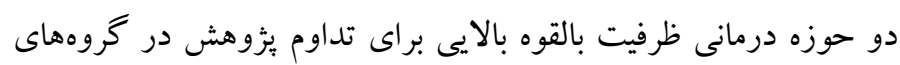

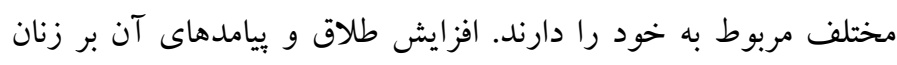
مطلقه، موجب مىشود تا باور نسبت به خود و توانمندىهايشان براى مرد

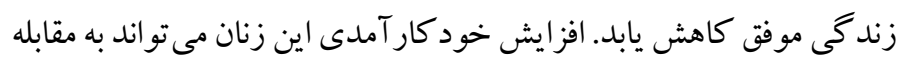

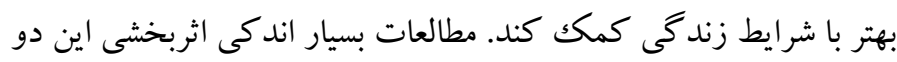

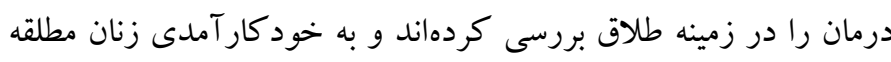
يرداختهاند، از طرفى هنوز مشخص نيست كدام يكك از اين دو درمان

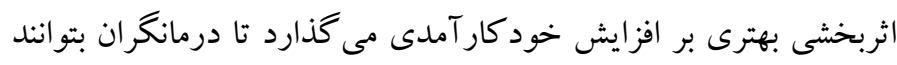

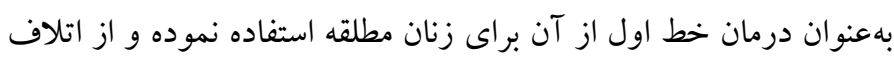

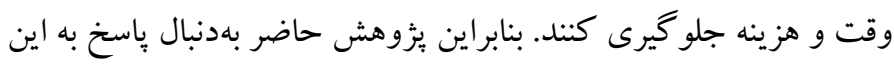

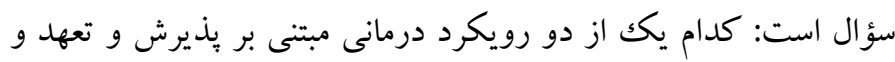

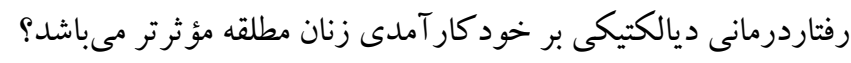

روش الف) طرح ئزوهش و شركت كنند انان: روش يُزوهش حاضر شبه

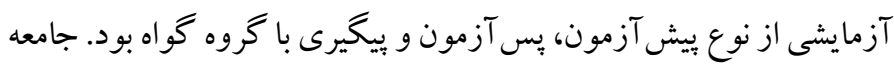

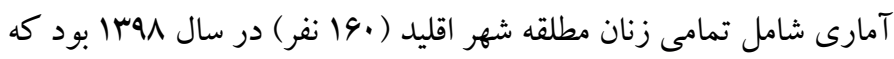
تحت يوشش ادارات بهزيستى و كميته امداد امامخمينى شهرستان اقليد

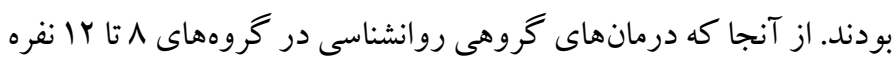

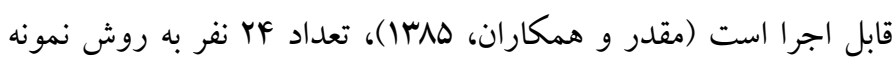

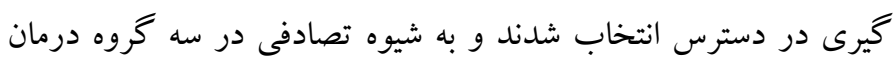

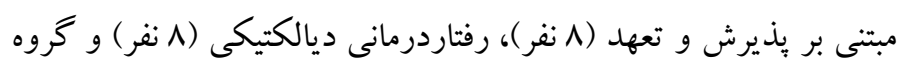

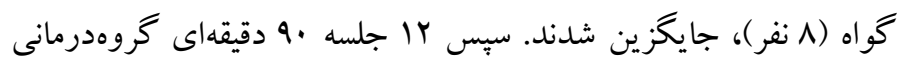


جدول ا. جلسات درمان مبتنى بر يذيرش و تعهد

\begin{tabular}{|c|c|c|c|}
\hline تكاليف & محتوا & اهداف & 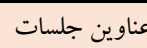 \\
\hline & 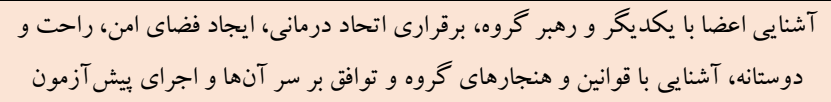 & 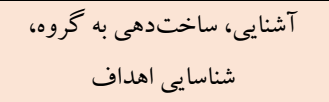 & اول \\
\hline ثبت مشكلات و تأثير آنها در زندگى & شناسايى و مقابله با رفتارهاى مشكل اعضا، برداختن به مشكلات احتمالى اعضا & شناسايى رفتارهاى مشكل اعضا & 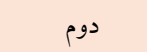 \\
\hline ثبت روش ها و راهكارهاى مورد استفاده تاكنون & بررسى تكاليف، شناسايى رفتارهاى مشكل اعضا، معرفى درمان مبتى بر يذيرش و تعهد، & $\begin{array}{l}\text { شناسايى رفتارهاى مشكل اعضاو } \\
\text { ACT معرفى درمان }\end{array}$ & 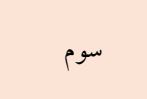 \\
\hline ثبت راهحل هاى نا كار آمد استفاده شده تاكنون و & 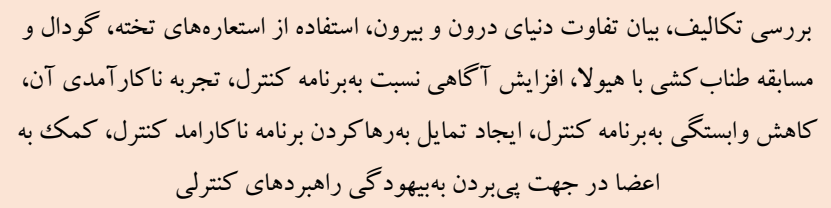 & ايجاد مفهوم درماندگى خلاق & جهارم \\
\hline تمرين توجه آكاهانه و استعاره لنكر انداختن & 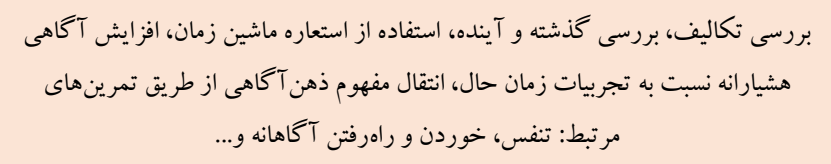 & زمان حال & ينجم \\
\hline تمرين ذهن آكاهى و تكميل كاربر گت بسط & 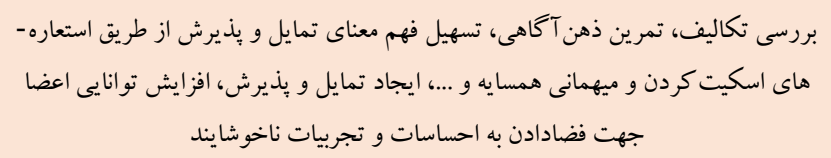 & 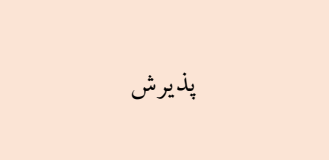 & ششم \\
\hline تمرين ذهن آكاهى و استفاده از تكنيكها در & 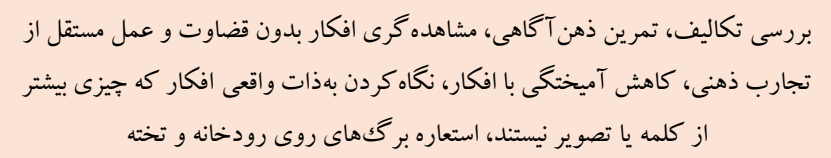 & همجوشىزدايى (كسلش) & 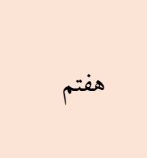 \\
\hline تمرين ذهن آكاهى و همجوشى و برردى تأيى در طول آن در زندگى شخصى و & 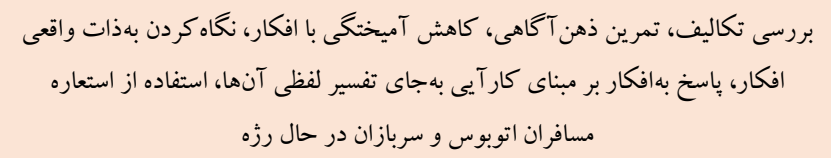 & همجوشىزدايى (گسلش) & هشتم \\
\hline 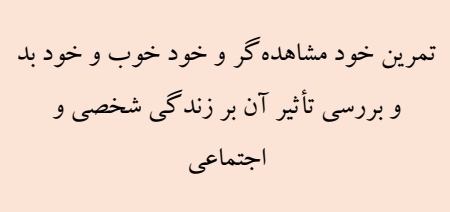 & 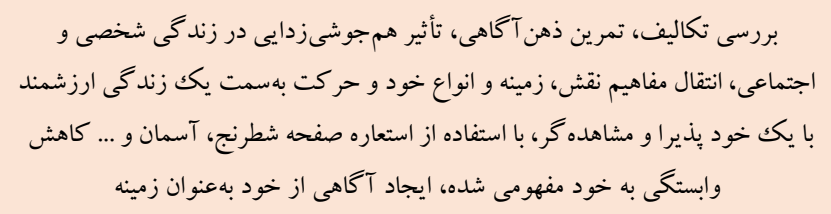 & خود به عنوان زمينه (خود مشاهده & نهم \\
\hline 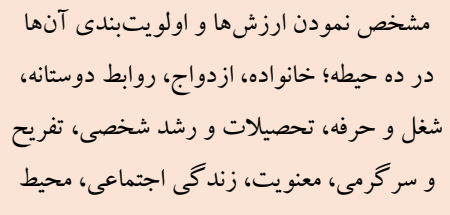 & 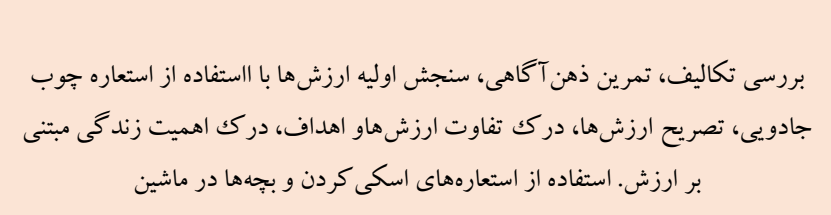 & 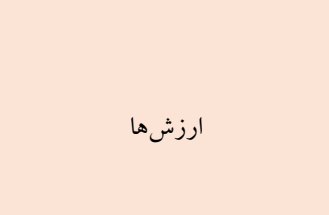 & دهم \\
\hline تكميل كاربر گت تمايل و عمل و به كار گيرى آموختها & 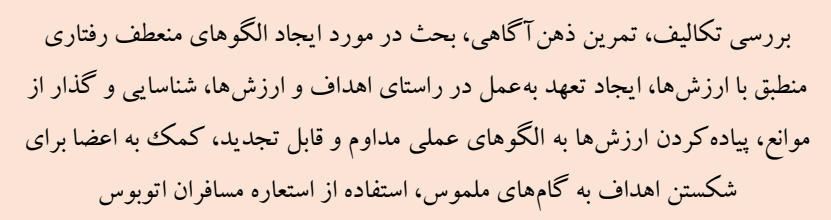 & عمل متعهدانه & 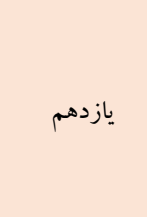 \\
\hline به كار گيرى آموختها & 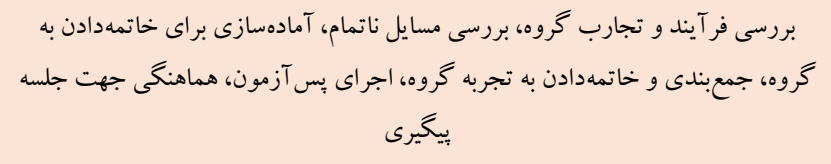 & جرعبى فر آيند و تجارب گروه، & 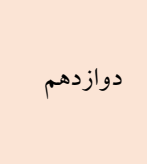 \\
\hline به كار كيرى آموختها & اجراى آزمونها & ارزيابى تداوم اثر درمان بعد از دو & ييخيرى \\
\hline
\end{tabular}


براى تدوين جلسات درمانى رويكرد رفتاردرمانى ديالكتيكى نيز از برنامه محتواى جلسات به شرح ذيل است:

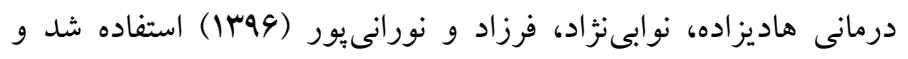

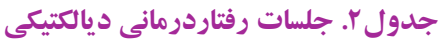

\begin{tabular}{|c|c|c|c|}
\hline تكاليف & محتوا & اهداف & عناوين جلسات \\
\hline & 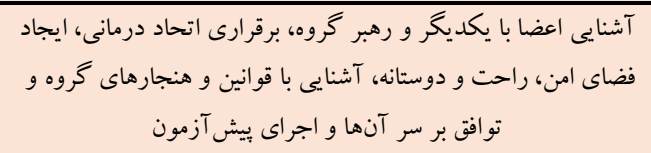 & آشنايى، ساخت دهى به گروه، & اول ال ال \\
\hline ثبت مشكلات و تأثير آنها در زندگى & 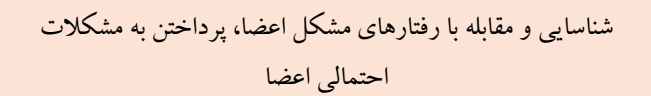 & شناسايى رفتارهاى مشكل اعضا & 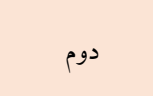 \\
\hline ثبت روشها و راهكارهاى مورد استفاده تاكنون & 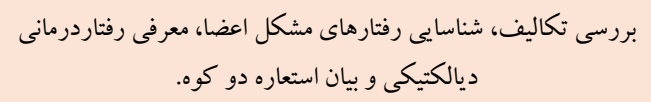 & $\begin{array}{l}\text { شناسايى رفتارهاى مشكل اعضا و معرفى درمان DBT } \\
\text { Dن }\end{array}$ & سوم \\
\hline ثبت مزايا و معايب تحمل و عدم تحمل هيجانهاى منفى، ثبت آثل & 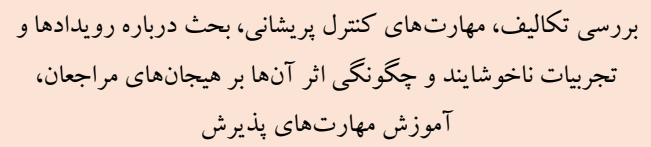 & مهارت تحمل يريشانى & جهارم \\
\hline به كار گيرى فنون ياد گرفته شده در موقعيتهاى مختلف، ارائه & بررسى تكاليف، مهارتهاى كنترل بريشانى، آموزش مهارت هاى & & \\
\hline 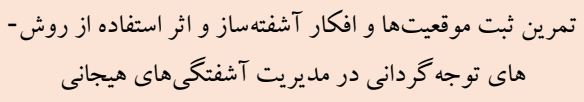 & 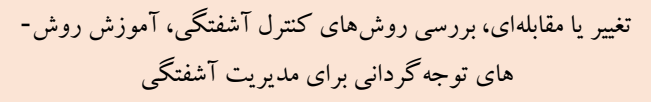 & مهارت تحمل بريشانى & ينجم \\
\hline 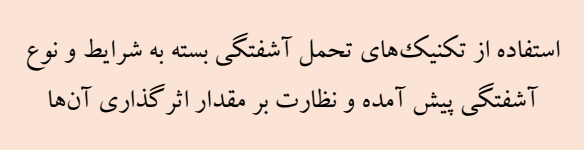 & 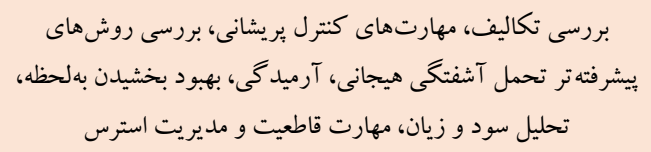 & مهارت تحمل بريشانى & 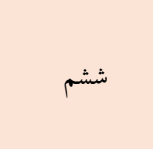 \\
\hline 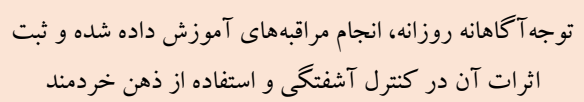 & بررسى تكاليف، مهارت هاى ذهن آكاهى، مهارتهاى اساسى و & مهارت ذهن آكاهى & هفتم \\
\hline 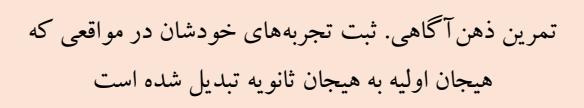 & 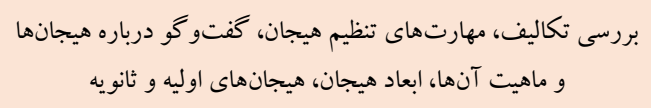 & مهارت تنظيم هيجان & هشتم \\
\hline 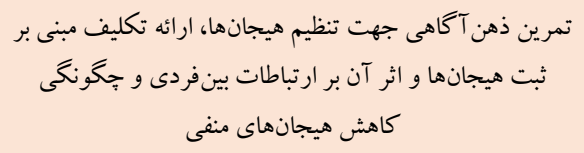 & ربر رسى تكاليف، تمرين ذهن آكاهى، مهارتهاى تنظيم هيجان، & مهارت تنظيم هيجان & نهم \\
\hline نظارت بر روشهاى برقرارى ارتباط، ثبت نوع الكوى ارتباطى - شان در روابط بين فردى & بحث دربى تكاليف، تمرين ذهن آكاهى، مهارت هاى بـ بين فردى مؤثر، & مهارت هاى بين فردى مؤثر & دهم \\
\hline 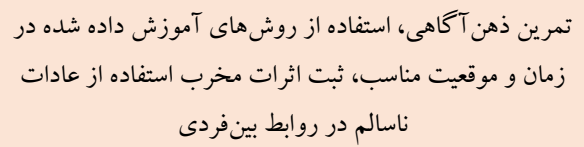 & بررسى تكاليف، تمرين ذهن آكاهى، مهارت هاى بين فردى مؤثر، & مهارت هاى بين فردى مؤثر & يازدهم \\
\hline & بررسى فر آيند و تجارب گروه، بررسى مسايل ناتمام، آمادهازى & بررسى فرآيند و تجارب گروه، & \\
\hline به كار گيرى آموختهها & 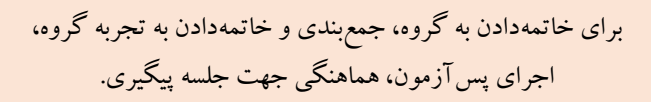 & جمعبندى جلسات، اجراى بس & دوازدهم \\
\hline به كار گيرى آموختها. & 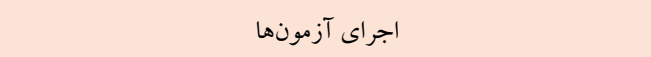 & ارزيابى تداوم اثر درمان بعد از دو ماه & 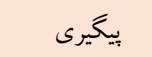 \\
\hline
\end{tabular}

سال بود. آزمون تحليل واريانس بهمنظور بررسى همسانى ميانگين سه گروه

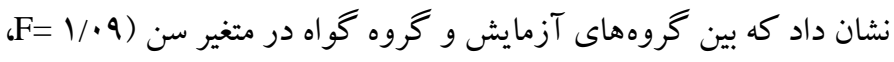
ه/p هاوت معنى دارى وجود ندارد.
كافتنه ها ويز كَىهاى جمعيت شناختى شر كت كنند كان گرووه نمونه در جدول بارائه شده است. رده سنى افراد شركت كننده بين هY تا وله قرار داشت. مدت ازدواج افراد شركت كننده بين ال تا سس سال و مدت طلاق زنان از ا تا ها 
جدول س. ويرَّى هاى جمعيت شناختى تروه نمونه

\begin{tabular}{|c|c|c|c|c|c|c|}
\hline \multicolumn{2}{|c|}{ گروه كو اه } & \multicolumn{2}{|c|}{ كروه آزمايش (DBT) } & \multicolumn{2}{|c|}{ كروه آزمايش (ACT) } & \multirow{2}{*}{ متغير } \\
\hline انحر اف استاندارد & ميانخين & انحراف استاندارد & ميانگين & انحراف استاندارد & ميانگين & \\
\hline r/ब9 & $r \Delta / 94$ & $V / r I$ & r & V/IT & $F \cdot / r V$ & 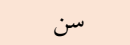 \\
\hline$\Delta / \Gamma \wedge$ & $19 / 1 \mathrm{r}$ & $V / r I$ & $10 / \Delta$ & $9 / 4 \pi$ & IV/VD & مدت ازدواج \\
\hline $4 / 9 \mathrm{~V}$ & $9 / 1 r$ & $r / 41$ & $\Delta / T \Delta$ & $\mathrm{r} / \Lambda \mathrm{F}$ & $\mathrm{V} / \mathrm{V} \Delta$ & مدت طلاق \\
\hline
\end{tabular}

و (DBT) در مراحل بس آزمون و بيخيرى با گروه گواه متفاوت است و

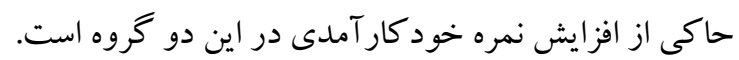

ميانگين نمرات گروههاى آزمايش و گواه در متغير خود كار آمدى در

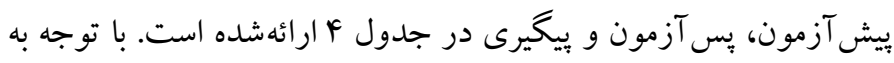

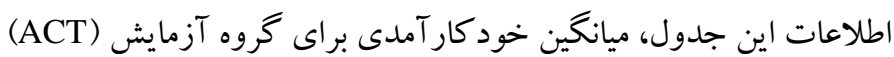

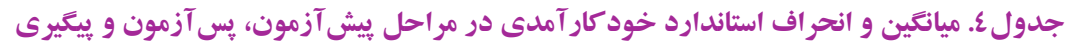

\begin{tabular}{|c|c|c|c|c|c|c|}
\hline \multicolumn{2}{|c|}{ كروه گواه } & \multicolumn{2}{|c|}{ كروه آزمايش (DBT) } & \multicolumn{2}{|c|}{ كروه آزمايش (ACT) } & \multirow{2}{*}{ متغير } \\
\hline انحراف استاندارد & ميانگين & انحراف استاندارد & ميانگين & انحر اف استاندارد & ميانگين & \\
\hline$r \Delta / / r$ & $F / V I$ & $r r$ & T/YG & $4 \cdot / 0$. & يُش آزمون & \\
\hline & $f / 11$ & FE/TD & $Y / q V$ & $0 \cdot / \Delta$. & يس آزمون & خود كار آمدى \\
\hline Mr/gr & $\Delta / Y F$ & $\mathrm{Fq/TV}$ & $r / .9$ & $\Delta F / I Y$ & ييخيرى & \\
\hline
\end{tabular}

برابرى واريانسها گروههاى آزمايشى و گو اه در متغيرهاى بثزوهش تأييد

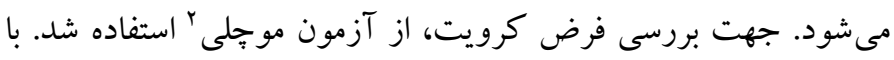

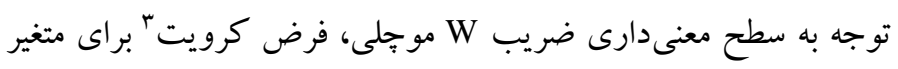

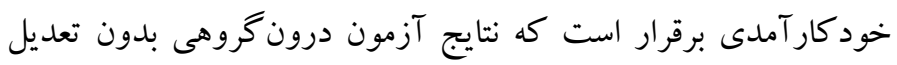

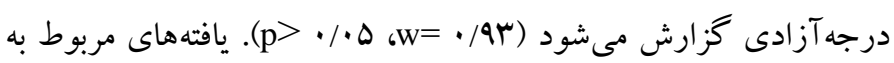
آزمون تحليل جندمتغيرى در جدول 9 ارائه شده است.

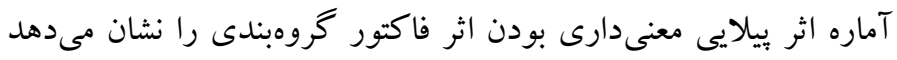

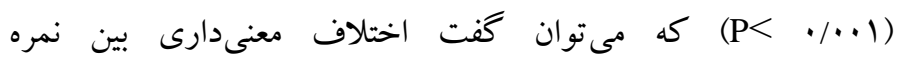
خود كار آمدى، در سه گروه ACT و DBT و گو اه وجود دارد. يافته هاى مربوط به آزمون تحليل واريانس اندازه مكرر در جدول V ارائه شده است.

${ }^{3}$. assumption of sphericity
قبل از بررسى فرضيه يُوهش، براى رعايت ييشفرضهاى تحليل

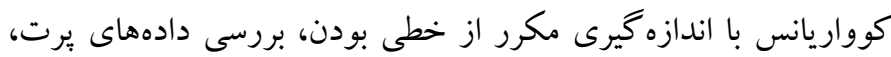

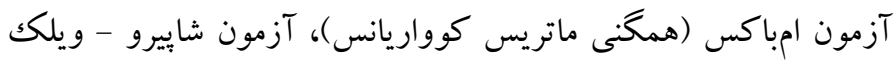

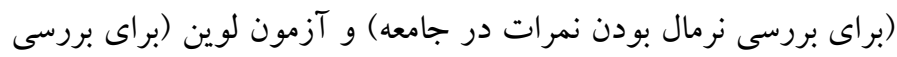

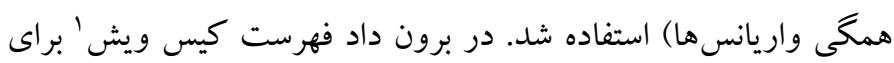

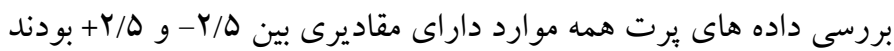

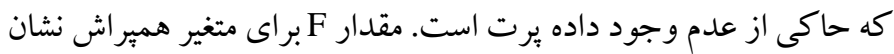

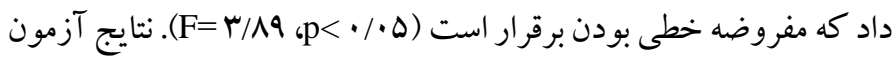
امباكس نشان مىدهد فرض همخنى ماتريس كواريانس - واريانس نيز

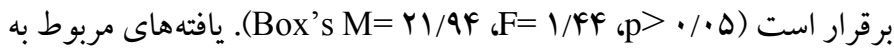
آزمون شابيرو - ويلك و آزمون لوين نيز در جدول ها ارائه شده است.

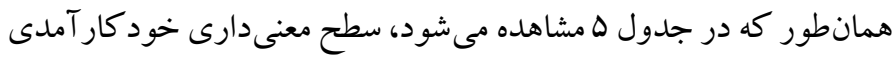

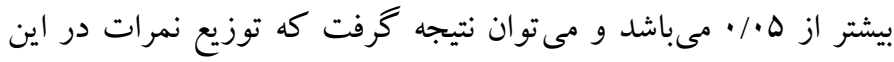

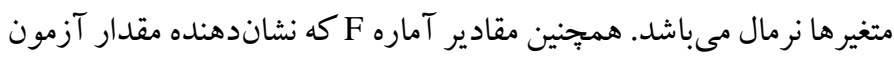

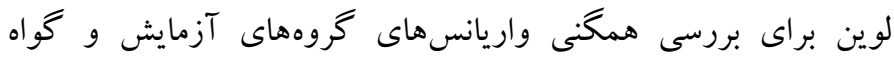

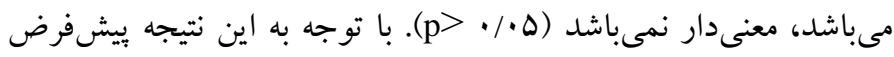

${ }^{1}$. Casewise list

2. Mauchly's Test 
جدوله. يافته هاى مربوط به بروسى فرض همعنى واريانس

\begin{tabular}{|c|c|c|c|c|c|c|c|c|c|c|c|}
\hline \multirow[b]{3}{*}{ معنى دارى } & \multirow{2}{*}{\multicolumn{2}{|c|}{ آزمون لوين }} & & \multicolumn{6}{|c|}{ آزمون شاييرو - ويلك } & & \multirow{3}{*}{ متغير } \\
\hline & & & & \multicolumn{2}{|c|}{ كروه گواه } & \multicolumn{2}{|c|}{ كروه آزمايش (DBT) } & \multicolumn{2}{|c|}{ كروه آزمايش (ACT) } & & \\
\hline & آزادى ب & آزادى ا درجه & 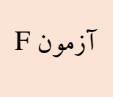 & معنى دارى & آماره & معنى مارى & آماره & معنى دارى & آماره & & \\
\hline.$/ .01$ & YI & $r$ & $r / \Lambda 1$ &.$/ 4 \Delta$ &.$/ 9 r$ & . $/$ TD & $\cdot / 19$ & $\cdot / V Y$ &.$/ 90$ & يِيش آزمون & \\
\hline$\cdot / \cdot 1$ & rI & $r$ & $r / V \wedge$ & .1 .9 & •/Ar & 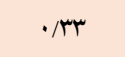 & $\cdot / 9$ & $\cdot / 41$ & $\cdot / 91$ & يس آزمون & خود كار آمدى \\
\hline$\cdot / \cdot V$ & rI & r & r/AV &.$/ 1$ & $\cdot / \wedge \Delta$ & . &.$/ 94$ & $\cdot / 4$ &.$/ 91$ & يِيخيرى & \\
\hline
\end{tabular}

جدول). يافته هاى مربوط به آزمون جندمتغيرى اثر يِلايى

\begin{tabular}{|c|c|c|c|c|c|c|c|}
\hline اندازه اثر & معنىدارى & خطا df & df فرضيه df & F & ارزش & منبع تغييرات & آزمون \\
\hline$\cdot / \mathrm{Vq}$ & $\cdot / \cdots 1$ & $r$. & $r$ & $\mathrm{rq/rq4}$ & ./VaV & درونگ كروهى & \multirow{2}{*}{ اثرييلايى } \\
\hline$\cdot / r V$ & $\cdot / \cdots 1$ & Fr & f & $9 / \pi F q$ & - NQF & بين گروهى & \\
\hline
\end{tabular}

\begin{tabular}{|c|c|c|c|c|c|c|c|}
\hline اندازه اثر & معنىدارى & F آماره F & ميانگين مجذورات & درجه آزادى & مجموع مجذورات & منبع & اثرات \\
\hline- & $\cdot / \cdots 1$ & $r \Delta / r \mu$ & $\Delta \wedge \Delta / \cdot \Delta \varphi$ & $r$ & $118 \cdot / 111$ & زمان & \multirow{3}{*}{ درون آزمودنى } \\
\hline- & $\cdot / \cdots 1$ & IY/AFV & rIr/r.G & F & NDT/YYY & تعامل زمان و گروه (اثر تعامل) & \\
\hline- & - & - & $19 / 9 \cdot r$ & Fr & 99V/rrr & خطا & \\
\hline 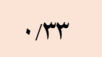 & $\cdot / \cdot 1$ & $\Delta / r r$ & $\mid r V \cdot / r \wedge q$ & r & rOF./WVA & 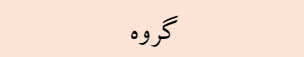 & \multirow{2}{*}{ بين آزمودنى } \\
\hline- & - & - & TFY/DQV & ri & $\Delta . Q F / D F Y$ & خطا & \\
\hline
\end{tabular}

تفكيك ارائه مى شود. ستون اندازه اثر نيز حاكى از تأثير سه درصدى درمان بر خود كار آمدى است. همجنين با توجه به نتايج جدول كه نشان مىدهد بين كروه و زمان تعامل وجود دارد (1) (p) مشخص مى كردد كه مراحل بيش آزمون، يس آزمون و بيخيرى بين كروههاى درمانى و كو اه نيز تفاوت وجود دارد. يافتههاى مقايسه زوجى بونفرونى بهمنظور بررسى

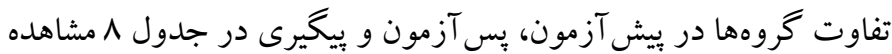

$$
\text { مى شود. }
$$

در جدول Vنتايج آزمون تحليل واريانس با اندازهگيرى مكرر براى بررسى اثرات درون آزمودنى و بين آزمودنى نشان داده شده است. همانطور كه ملاحظه مى گردد در اثر زمان، خود كار آمدى معنىدار شده است

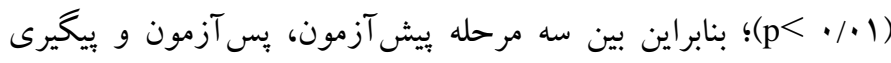
تفاوت وجود دارد. همجنين در اثر كروه نيز با توجه به مقادير F و سطوح معنى دارى مشاهده مىشود كه بين دو كروه آزمايش و كواه تفاوت معنىدار وجود دارد (1)

جدول^ه. مقايسه زوجى بونفرونى كروههاى آزمايشى و كواه در مر احل سنجش در متغير خود كار آمدى

\begin{tabular}{|c|c|c|c|c|c|c|c|}
\hline \multicolumn{2}{|c|}{ اختلاف ميانكين } & \multirow[t]{2}{*}{ معنى دارى } & \multirow[t]{2}{*}{ خطاى استاندارد } & \multirow[t]{2}{*}{ اختلاف ميانگين (I-J) } & \multirow[t]{2}{*}{ كروه (J) } & \multirow[t]{2}{*}{ (I) كروه } & \multirow[t]{2}{*}{ 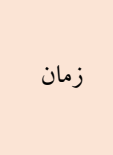 } \\
\hline حد بالا & حد بايين & & & & & & \\
\hline 19/rr & - & $\cdot / r$ & $F / \Delta F$ & $V / \Delta$ & رويكرد DBT & \multirow{2}{*}{ رويكرد ACT } & \multirow{4}{*}{ يش آزمون } \\
\hline$|V / r|$ & $-9 / 49$ & $\cdot / V$ & $F / \Delta F$ & $\Delta / M V$ & كواه & & \\
\hline p/rr & $-19 / \pi r$ & $\cdot / \mu$ & $F / \Delta F$ & $-V / \Delta$ & رويكرد ACT & \multirow{2}{*}{ رويكرد DBT } & \\
\hline $9 / 71$ & $-1 \% / 99$ & 1 & $F / \Delta F$ & $-r / I r$ & كواه & & \\
\hline $19 / 1 Y$ & $-V / 9 Y$ & 1 & $F / \Delta Q$ & $F / Y \Delta$ & رويكرد DBT & رويكرد ACT & يس آزمون \\
\hline
\end{tabular}




\begin{tabular}{|c|c|c|c|c|c|c|c|}
\hline \multicolumn{2}{|c|}{ فاصله اطمينان هو درصد براى اختلاف ميانخين } & \multirow[t]{2}{*}{ معنى دارى } & \multirow[t]{2}{*}{ خطاى استاندارد } & \multirow[t]{2}{*}{ اختلاف ميانكين (I-J) } & \multirow[t]{2}{*}{ كروه (J) } & \multirow[t]{2}{*}{ (I) كروه } & \multirow[t]{2}{*}{ زمان } \\
\hline حد بالا & حد بايين & & & & & & \\
\hline$r q / Y F$ & $\Delta / \Delta$ &.$/ \mu$ & $F / \Delta q$ & $I V / r V$ & كواه & & \\
\hline V/AT & $-19 / 1 Y$ & 1 & F/DG & $-F / r \Delta$ & رويكرد ACT & \multirow{2}{*}{ رويكرد DBT } & \\
\hline$r F / Q q$ & $1 / r \Delta$ & $\cdot / \cdot r$ & $F / \Delta \varphi$ & $1 r / 1 r$ & كواه & & \\
\hline $11 / r^{4}$ & $-\Lambda / \wedge 9$ & 1 & $\Delta / Y \mu$ & $F / v \Delta$ & رويكرد DBT & \multirow{2}{*}{ رويكرد ACT } & \\
\hline$\mu F / 11$ & $9 / M 1$ & $\% r$ & $\Delta / Y r$ & $r \cdot / \Delta$ & كو اه & & \\
\hline N/A9 & $-11 / 49$ & 1 & L/Y & $-F / v \Delta$ & رويكرد ACT & \multirow{2}{*}{ رويكرد DBT } & \\
\hline$r q / r_{G}$ & $r / I r$ & $\cdot / r$ & $\Delta / r \mu$ & $10 / v \Delta$ & كواه & & \\
\hline
\end{tabular}

درونى براى تغيير يا كاهش حضور در لحظه حال يا آينده بدون تلاش است (توهيخك و لوين، IV IV). هنگامى كه زنان مطلقه شر ايط و موقعيت خود را مى بذيرند، با آن روبرو مىشوند و از آنها اجتناب نمى كنند، مىتوانند برآورد مناسبى از اين شرايط داشته باشند و خود را براى مقابله با آن دست كم نمى گيرند. به نظر مىرسد بذيرش باعث مىشود آنها توانمندى هايشان را باور كنند و خودكار آمدى بالايى براى مقابله با موقعيت ها به دست آورند. در تبين ديخر مى توان بيان كرد كه يكى از اهداف درمان يذيرش و تعهد، افزايش انعطاف يذيرى روانشناختى و كاهش انعطافنايذيرى است. انعطاف يذيرى در زنان مطلقه يايين است (باقرى، اسدى و خواجه وند خوشلى، 19 (Y). در اين درمان به افراد آموزش داده مىشود تا بتوانند با تجارب درونى خود ارتباط برقرار كنند، به اين تجارب اجازه دهند در صورت مفيد بودن، حضورداشته باشند، افكار را فقط بهعنوان افكار بييند، يكك حس قوى براى جهت دهیى زندكى داشته باشند و مواردى كه معنادار

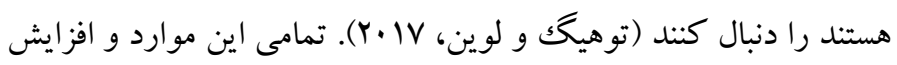
انعطاف يذيرى روانشناختى به زنان مطلقه كمكك مى كند تا خود را فرد ضعيفى كه در شرايطى در گير شده كه نمىتواند كارى انجام دهد و توسط افكار، احساسات و تجارب منفى محصورشده، نبيند و باورشان در مورد توانايىهايشان تغيير كند. آنها براى معنادهى زندگى خود، به توانمندى هايشان ايمان بيدا مى كنند و قضاوت هايشان درباره توانايى هايشان براى به ثمر رساندن عملكردها مثبت و ساز كار انه مىشود و با خود كار آمدى بالا با

$$
\text { موقعيت ها برخورد مى كنند. }
$$

ناهم آميختخى، بهو سيله تغيير معنادهى به كلمات و انتقال آنها به يكك زمينه متفاوت از جايى كه معمولاً بروز مى كنند، عملكرد افكار را ضعيف مى كند
همانطور كه انتظار مىرفت در مرحله بيش آزمون سه گروه درمان مبتنى بر يذيرش و تعهد و رفتاردرمانى ديالكتيكى و كواه داراى ميزان خود كار آمدى يكسانى بودهاند؛ اما به دليل معنى دار شدن اختلاف ميانگين خود كار آمدى بين كروه درمان مبتنى بر بذيرش و تعهد و كو اه و همجنين معنى در يس آزمون، دو روش درمانى مبتنى بر يذيرش و تعهد و رفتاردرمانى ديالكتيكى اثربخش هستند (ه •/ > p)؛ بنابر اين مى توان كفت كه دو روش درمانى بر ميزان خود كار آمدى فرد اثر كذار است. از طرفى آزمون مقايسه ميانگين خود كارآمدى بين دو كروه درمان مبتنى بر يذيرش و تعهد و رفتاردرمانى ديالكتيكى معنى دار نيست (ه •/ > > ) و اين دو روش درمان از نظر اثر كذارى بر ميزان خود كار آمدى فرد، در يس آزمون يكسان هستند ولى در مرحله ييخيرى فقط در مورد گروه درمان مبتنى بر يذيرش و تعهد معنى دار است.

\section{بحث و نتيجه Fيرى}

هدف يثروهش حاضر، مقايسه اثربخشى گروهدرمانى مبتنى بر يذيرش و تعهد و رفتاردرمانى ديالكتيكى بر خود كار آمدى زنان مطلقه بود. همانطور كه نتايج يثوهش نشان مى دهد هر دو روش درمانى يذيرش و تعهد و رفتاردرمانى ديالكتيكى مى توانند بر افز ايش خود كار آمدى زنان مطلقه مؤثر

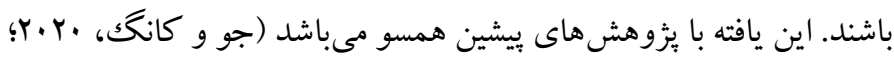

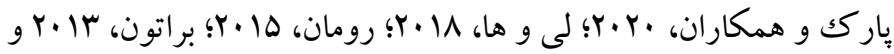

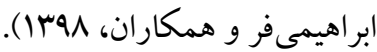
در تبيين اثربخشى درمان مبتنى بر يذيرش و تعهد مىتوان گفت يذيرش نقطه مقابل اجتناب تجربى است. يذيرش شامل اجازه دادن به تجارب 
آموزش مهارتهاى ارتباطى و ارتباط مؤثر و غير مؤثر در رفتاردرمانى

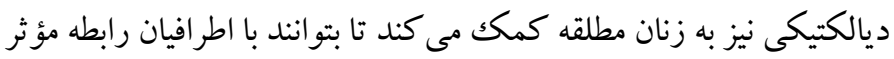

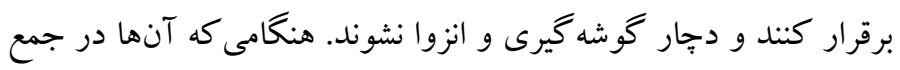

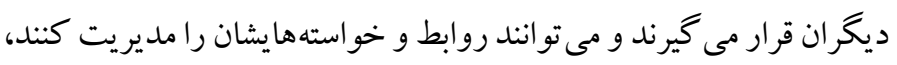

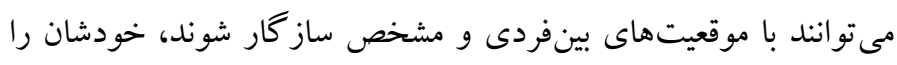

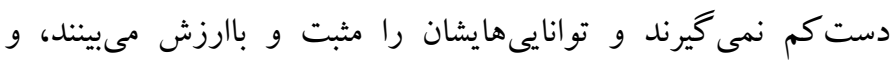
خود كار آمدى بيشترى بيدا مى كنند.

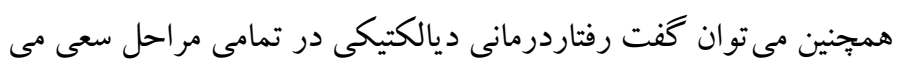

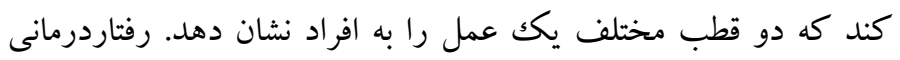

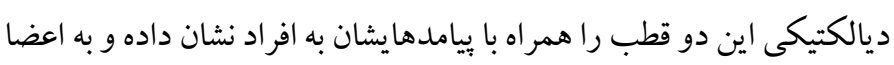

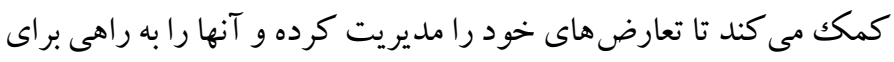

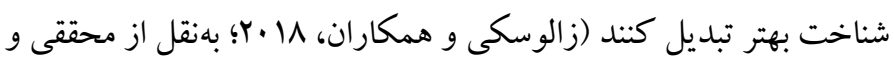

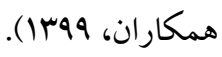
يافتها تفاوت معنى دارى را در مقايسه دو گروهدرمانى مبتنى بر يذيرش و

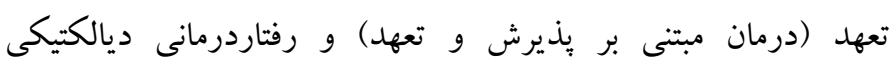

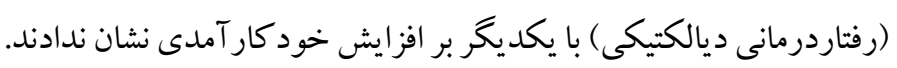

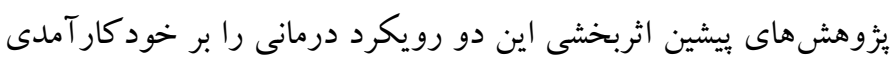
زنان مطلقه مورد آزمون قرار نداده بودند.

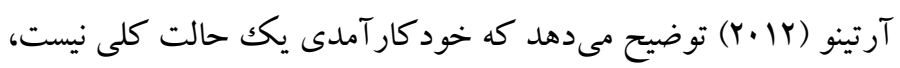
بلكه شفقت به خود است كه مختص شرايط و محيط فعاليت است. هر دو

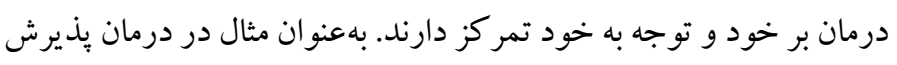

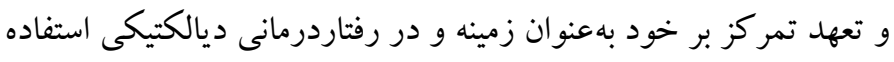

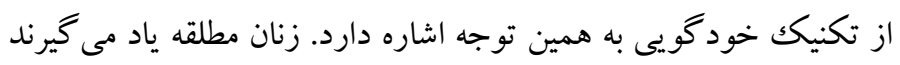

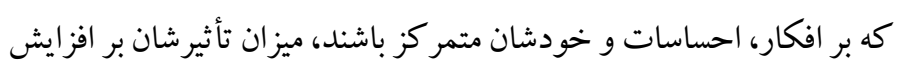
خود كار آمدى اين زنان نيز يكسان است.

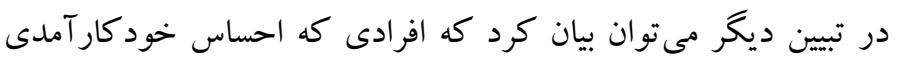
بالايى دارند معتقدند كه مىتوانند به نحو مؤثرى با وقايع و موقعيتها برخورد كنند (حسينى دولتآبادى و همكاران، سوسا) و با استفاده از راهبردهاى مختلف، اضطراب و استرس كمترى را تجربه كنند (دهقان

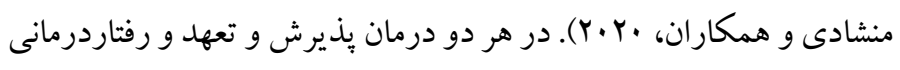
ديالكتيكى مهارتهايى را به زنان مطلقه آموزش مى دهند كه آنها بتو انند دماند

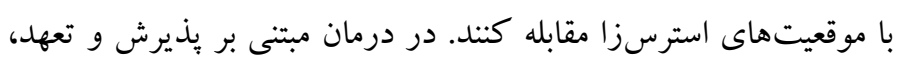

(يرادنزى و همكاران، 19 19). با توجه به تأكيد درمان مبتنى بر يذيرش و

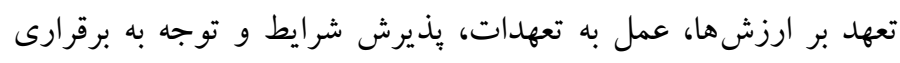

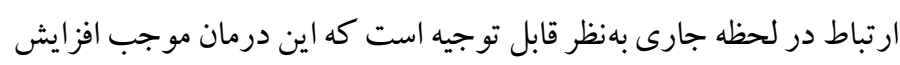

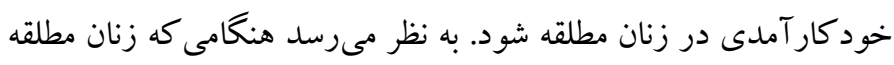

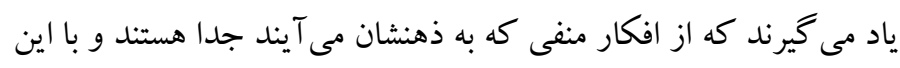
افكار يكى نيستند و عملكرد اين افكار تضعيف ييدا مى كند، خود كار آمدى آنى افزايش مى يابد و قضاوت مثبت ترى نسبت به خود و توانايى هايشان براى ئى

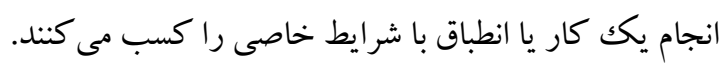
در تبيين اثربخشى رفتاردرمانى ديالكتيكى بر افزايش خود كار آمدى بارئ

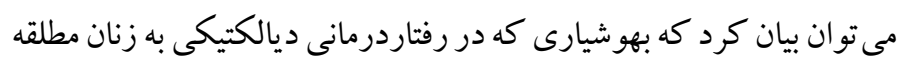

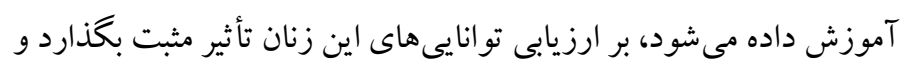

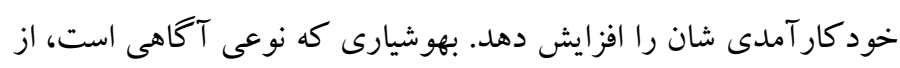
طريق شناخت آكاهانه و قضاوت عينى كه بر لحظه كنونى تمر كز مى شود و از تداخل احساسات، حافظه و خيال در زندگى يا كار كنونى جلو گيرى

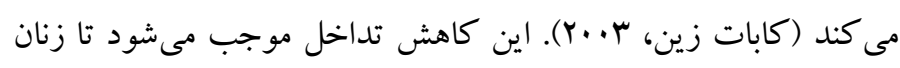
مطلقه توانايى ادراككشده خود را براى مو اجهه با مشكلات و موقعيت زهاى مختلف مثبت ارزيابى كنند و خود كار آمدى شان افزايش يابد. تحمل يريشانى، بهعنوان شاخصهاى ادراككشده يا واقعى براى تحمل

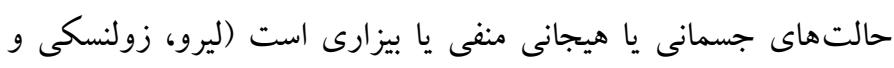

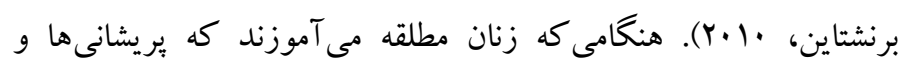

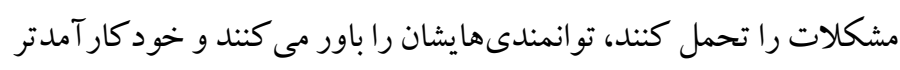
عمل مى كنند. در تبيين ديخر مى توان بيان كرد زنان بس از طلاق احساسات و هيجانهاى

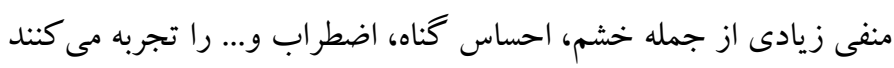

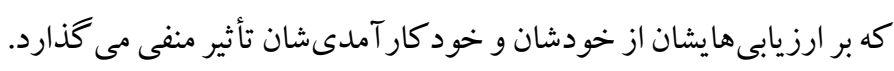
تنظيم هيجان، يكى از روشهايى است كه در رفتاردرمانى ديالكتيكى مورد

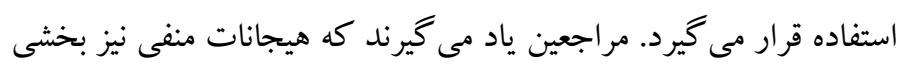

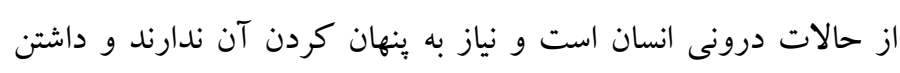
احساسات منفى بس از جدايى روند طبيعى محسوب مى شوند. باور منفى و

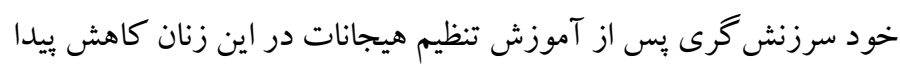

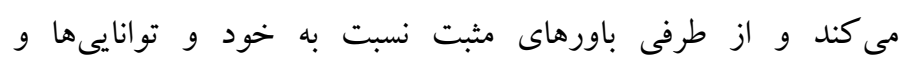
خود كار آمدى شان افز ايش مى يابد. 
(در گروه رفتاردرمانى ديالكتيكى) در مرحله بيخيرى توصيه مىشود

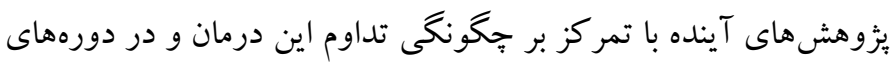

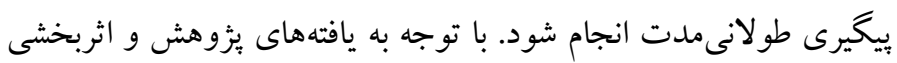

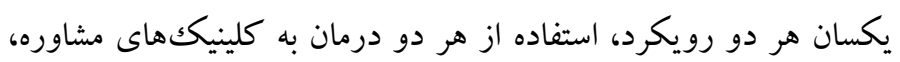
متخصصين حوزههاى خانواده و درمانهاى فردى، بهمنظور كمكك به اين

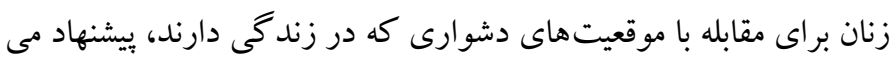
كردد.

ملاحضات اخلاقى بيروى از اصول اخلاق ثئوهش: اين مقاله بركرفته از رساله دكترى نويسنده اول در

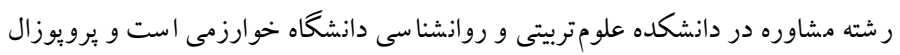

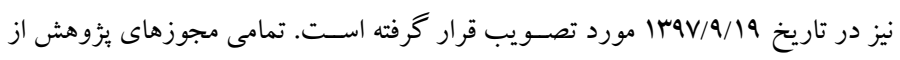

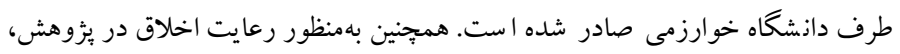

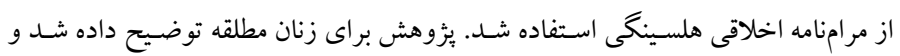

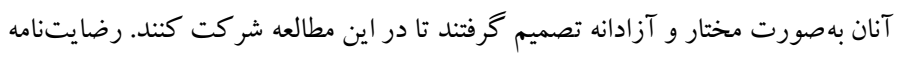

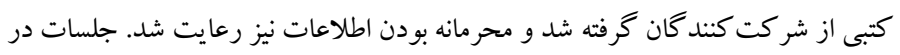

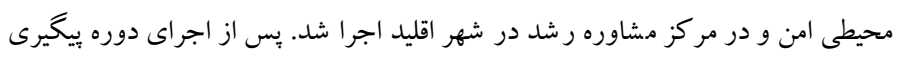

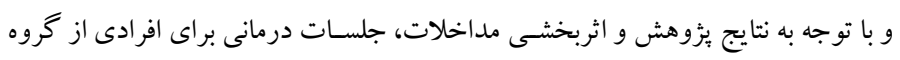
كنترل كه تمايل داشتند نيز اجرا خرديد.

حامى مائى: اين يُؤهش در قالب رساله دكترى و بدون حمايت مالى مى إشاشد.

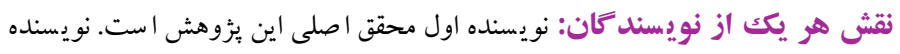
دوم استاد راهنما و نويسنده سوم استاد مشاور رساله مىباشند.

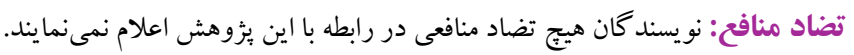

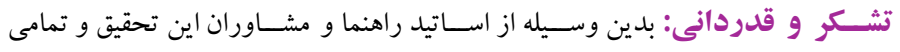
مر اجعينى كه در انجام اين تحقيق يارى نمودند تشكر و قدردانى مى خردد.
شركت كنند كان از طريق تكنيكهاى مقابله با رفتارهاى مشكل، اتخاذ

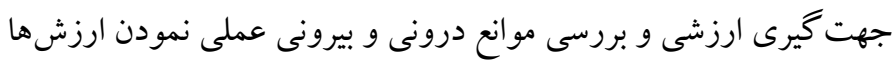

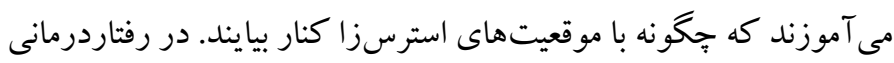

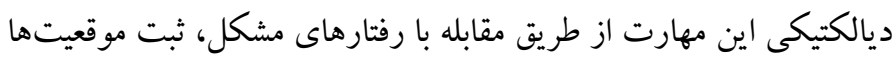

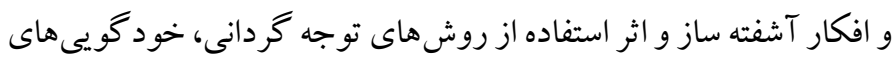

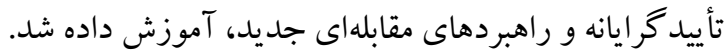
از محدوديتهاى اين بثزوهش اين است كه مىبايست در تعميم يافتها

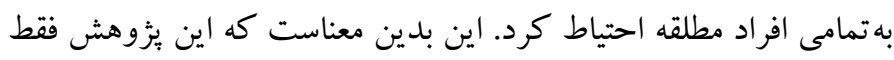

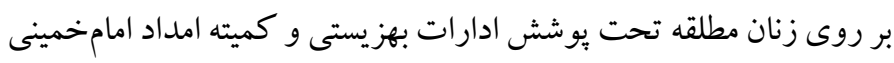

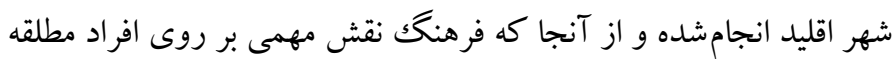
بازى مى كند و اثربخشى رويكردهاى بثزوهش بر روى زنان مطلقه در

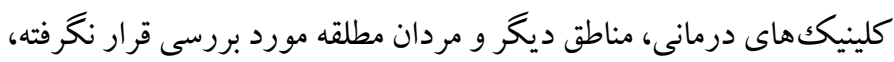

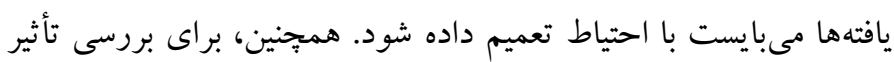

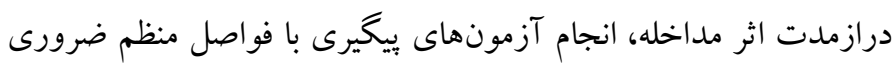

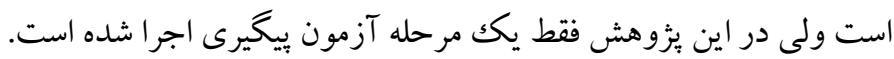

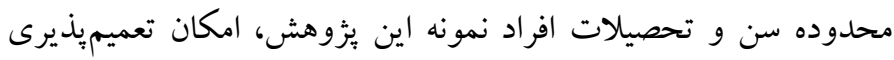
نتايج را به ساير گروهها مشكل مى كند.

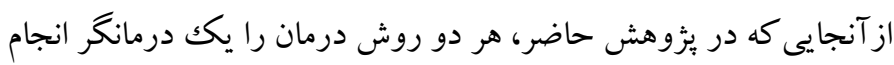

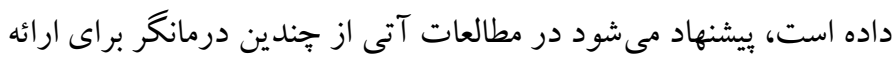

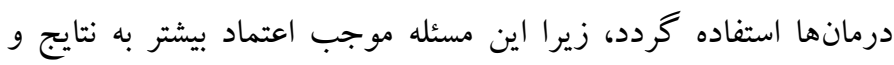

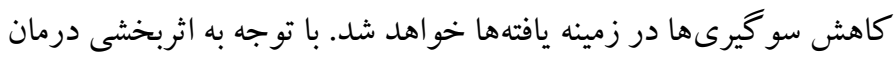

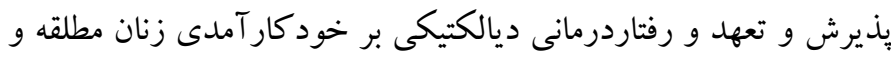
تداوم و افزايش آن در پس آزمون و در عين حال معنىدار نبودن اين يافته دئه 


\section{References}

Civil Registration Organization (2020). Marriage and divorce. [Link]

Abdul Rahimi Noshad, L. (2020). Effectiveness of Acceptance-Commitment Therapy on selfregulation and self-efficacy among women with addictions to stimulants. New Advances in Behavioral Sciences, 5(49), 1-12. (Persian). [Link]

Honarvaran, N., Mirzaei-Kia, H., Nairi, A., \& Lotfi, M. (2014).Practical guidebook of therapists on acceptance and commitment-based treatment. Tehran: Hamneshin. (Persian). [Link]

Najafi, M., \& Foladjang, M. (2007). The relationship between self-efficacy and mental health among high school students. Clinical Psychology and Personality, 5(1), 69-83. (Persian). [Link]

Moghtader, L., Hasanzade, R., Mirzaeian, B., \& Dusti, Y. (2016). Effectiveness of group cognitive behavioral therapy and group cognitive hypnotism on anxiety and depression in women with premenstrual syndrome. Journal of Holistic Nursing And Midwifery, 26(3), 96-105. (Persian). [Link]

Dehghan Manshadi, Z., Doost, H. T. N., Talebi, H., \& Vostanis, P. (2020). Coping strategies among Iranian children with experience of Sarpol-e-Zahab earthquake: factor structure of children's Coping Strategies Checklist-revision1 (CCSC-R1). BMC psychology, 8(1), 1-12. [Link]

Keramati, H., \& Shahr-Arai, M. N. (2004). Investigating the relationship between self-perceived efficacy and performance on mathematics among junior high school students. Educational Innovations, 3(4), 103115.. (Persian). [Link]

Yazdi, S. A. H., Mashhadi, A., Kimiaee, S. A., \& Asemi, Z. (2015). Effectiveness of Children of Divorce Intervention Program (CODIP) on externalized and internalized problems in children of divorce. Ijfp, 2 (1), 3-14.. (Persian). [Link]

Hadizadeh, M. H., Navabinejad, S. H., Farzad, V., \& Nooranipour, R. (2017). Effectiveness of dialectical behavior therapy on self-efficacy and interpersonal problems of women with dependent personality disorder. Journal of Woman and Society, 8(2), 97114.. (Persian). [Link]

Keramati, H., \& Shahr-Arai, M. N. (2004). Investigating the relationship between self-perceived efficacy and performance on mathematics among junior high school students. Educational Innovations, 3(4), 103115.. (Persian). [Link]

Kiani, S., Sabahi, P., Hosseini, S. M., Rafienia, P., \& Alebouyeh, M. (2020). Comparison of the effectiveness of acceptance and commitment-based therapy and positive cognitive-behavioral therapy on the pain self-efficacy of patients with chronic pain. Journal of psychologicalscience, 19(89), 567578.. (Persian). [Link]

Mohagheghi, H., Mahdikhanloo, M., Parsinejad, Z., \& Ashori, A. (2020). The effectiveness of dialectic behavior therapy on pain self-efficacy and experiential avoidance in the mothers with irritable bowel syndrome. Journal of psychologicalscience, 19(88), 439-449.. (Persian). [Link]

Ebrahimifar, M., Hosseinian, S., Tosi, M. R. S., \& Abedi, M. R. (2019). To compare of the effectiveness of training based on "Acceptance and Commitment Therapy" and "Compassion Focused Therapy" on self-efficacy, quality of relations and meaning in life in infertile women. Journal of Health Promotion Management, 8(3), 10-18. (Persian). [Link]

Bakhtiari Said, B., Zahrakar, K., Kasaee, A., \& Tajikesmaeili, A. (2020). The effectiveness of group counseling on acceptance-based therapy (ACT) on the organizational commitment of university staffs. Journal of psychologicalscience, 19(91), 833-843.. (Persian). [Link]

Artino, Jr. A.R. (2012). Academic self-efficacy: from educational theory to instructional practice. Perspective Medical Education, 1 (2), 76-85. [Link]

Asadpour, E., \& Hosseini, M. S. (2018). The Effectiveness of Cognitive Group Therapy on Self-efficacy and Depression among Divorced Women. Journal of Practice in Clinical Psychology, 6(4), 231-238. [Link]

Bagheri, S., Asadi, J., \& Khajevand Khoshli, A. (2019). The Effect of Solution-Focused Couple Therapy on Communication Patterns and Flexibility in Divorce Applicant Couples. Avicenna Journal of Neuro Psycho Physiology, 6(3), 133-140. [Link]

Bruton, W. S. (2013). The impact of a DBT training on the counselor self-efficacy of pre-service counselors working with borderline personality disordered clients. Doctor of Philosophy, Oregon State University, United States.[Link]

Crosby, J. M. \& Twohig, M. P. (2016). Acceptance and commitment therapy for problematic internet pornography use, a randomized trial. Behavior Therapy, 47(3), 355-366. [Link]

Haerazi, H., \& Irawan, L. (2020). The effectiveness of ECOLA technique to improve reading comprehension in relation to motivation and selfefficacy. International Journal of Emerging Technologies in Learning (IJET), 15(1), 61-76. [Link] 
Hayes, S. C. Strosahl, K. D. \& Wilson, K. (2014). Measuring experiential avoidance: A preliminary test of a working model. Psychological Record, 54 (4), 553-578. [Link]

Kabat-Zinn, J. (2003). Mindfulness-based interventions in context: Past, present, and future. Clinical Psychology: Science and Practice, 10(2), 144-156. [Link]

Kurbanoglu, S. S. (2003). Self-Efficacy: A concept closely linked to information literacy and lifelong learning. Journal of Documentation, 59(6), 635-646. [Link]

Lee, J. W., \& Ha, J. H. (2018). The effects of an acceptance-commitment therapy based stress management program on hospitalization stress, selfefficacy and psychological well-being of inpatients with schizophrenia. Journal of Korean Academy of Nursing, 48(4), 443-453. [Link]

Leyro, T. M., Zvolensky, M. J., \& Bernstein, A. (2010). Distress tolerance and psychopathological symptoms and disorders: A review of the empirical literature among adults. Psychological Bulletin, 136(4), 576-600. [Link]

Linehan, M. M. (1993). Cognitive-behavioral treatment of borderline personality disorder. New York: Guilford Press. [Link]

Linehan, M. M. (2015). DBT skills training manual. New York: Guilford Press. [Link]

Linehan, M. M., \& Wilks, C. R. (2015). The course and evolution of dialectical behavior therapy. American journal of psychotherapy, 69(2), 97-110. [Link]

Park, J. H., Ju, S. J., \& Kang, G. Y. (2020). The effects of dialectical behavior therapy (DBT) skill training on depression and alcohol abstinence self-efficacy of patients with alcohol use disorder. Medico Legal Update, 20(1), 1497-1503.[Link]

Prudenzi, A., Rooney, B., Presti, G., Lombardo, M., Lombardo, D., Messina, C., \& McHugh, L. (2019). Testing the effectiveness of virtual reality as a defusion technique for coping with unwanted thoughts. Virtual Reality, 23(2), 179-185. [Link]

Roman, K. M. (2015). Self-efficacy and its relation to skills coaching in the context of dialectical behavior therapy augmented with a mobile phone app. Doctoral dissertation, Rutgers University-Graduate School of Applied and Professional Psychology. [Link]

Seif, S. (2004). The differential study of outcome divorce rate in Iranian and American men and women. Family and Research, 1(1), 81-104 (Persian). [Link]

Siddiqui, S. (2015). Impact of self-efficacy on psychological well-being among undergraduate students. The International Journal of Indian Psychology, 2(3), 5-16. [Link]

Twohig, M. P., \& Levin, M. E. (2017). Acceptance and commitment therapy as a treatment for anxiety and depression: A review. Psychiatric Clinics, 40(4), 751-770. [Link] 